\title{
Pengaruh Faktor Fundamental Terhadap Return Saham Serta Dampaknya pada Nilai Perusahaan Otomotif di Indonesia
}

\author{
Ani Meryati ${ }^{1}$ \\ 1,2) Universitas Pamulang, annym3r@gmail.com
}

\section{ARTICLES \\ INFORMATION}

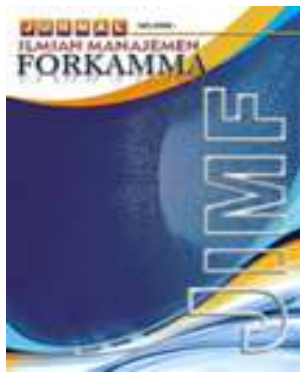

\section{JURNAL ILMIAH MANAJEMEN FORKAMMA}

Vol.3, No.3, Juli 2020

Halaman : $283-295$

(c) LPPM \& FORKAMMA

Prodi Magister Manajemen

UNVERSITAS PAMULANG

ISSN (online) : 2599-171X

ISSN (print) : 2598-9545

Keyword :

Faktor Fundamental; Return

Saham; Nilai Perusahaan

JEL. classification :

C33, G21, G34, N25

Contact Author :

PRODI

MAGISTER MANAJEMEN \& FORKAMMA UNPAM

JL.Surya Kencana No.1 Pamulang

Tangerang Selatan - Banten

Telp. (021) 7412566, Fax (021) 7412491 Email :

jurnalforkamma.unpam@gmail.com
Faktor fundamental mempunyai pengaruh kuat terhadap Return Saham, karena faktor fundamental menunjukkan kinerja keuangan perusahaan. Riset ini menggunakan data sekunder sebagai sumber riset. Sampel yang digunakan yaitu DER, CR, ROE, dan ROA terhadap Return Saham serta Serta Dampaknya pada Nilai Perusahaan Otomotif di Indonesia yang tercantum pada periode 2010-2016 di BEl. Deskriptif kuantitatif, tipe riset ini. Teknik analisis menggunakan regresi data panel, kemudian perhitungannya menggunakan program Eviews versi 9. Berdasarkan hasil riset pada taraf signifikansi $5 \%$ menunjukkan bahwa empat hipotesis diterima kecuali dua hipotesis yang berpengaruh negatif. Secara parsial DER dan $\mathrm{CR}$ berpengaruh negatif terhadap Return Saham. Partially ROE, Nilai Perusahaan (PBV), dan ROA berpengaruh positif pada Return Sạham. Simultaneously variabel DER, CR, ROE, dan ROA berpengaruh positif terhadap Return Saham.

Fundamental factors have a strong influence on Return Saham, because fundamental factors indicate the company's financial performance. This research uses secondary data as a source of research. The sample used is DER, CR, ROE, and $R O A$ on Return Saham and its impact on the value of automotive companies in Indonesia listed in the 2010-2016 period on the Indonesia Stock Exchange. Quantitative descriptive, this type of research. The analysis technique uses panel data regression, then the calculation uses the Eviews version 9. Based on the results of research at a significance level of 5\% shows that four hypotheses were accepted except for two hypotheses that had negative effects. Partially DER and CR negatively affect Return Saham. Partially ROE, Company Value (PBV), and ROA have a positive effect on Return Saham. Simultaneously the DER, CR, ROE, and ROA variables have a positive effect on Return Saham. 


\section{A. PENDAHULUAN}

Setiap tahunnya Bursa Efek Indonesia di Indonesia (BEI) terus mengalami perkembangan. Seiring perkembangannya, menjadikan sarana yang efektif untuk mempercepat pertumbuhan keuangan terutama pada setiap perusahaan go public. Pemerintah saat ini sedang gencar-gencarnya memperkenalkan dan memberikan pengetahuan pasar modal kepada masyarakat agar timbul keinginan dan kesadaran untuk melakukan investasi, serta menjadikan hal ini sebagai gaya hidup masyarakat dalam memanfaatkan peluang bisnis.

Sejalan dengan tujuan pemerintah untuk mengacu pada tiga misi utama industri nasional yaitu 1) Pertumbuhan ekonomi di atas 7\%. 2) Peningkatan daya tarik investasi dan daya saing bangsa. 3) Penciptaan lapangan kerja dan penurunan angka kemiskinan maka terdapat 10 klaster industri yang akan dikembangkan sesuai dengan perannya. Industri otomotif dan komponen otomotif (Kamar Dagang dan Industri Indonesia 2010) merupakan salah satu klaster industri unggulan yang berperan mendongkrak pertumbuhan ekonomi di atas $7 \%$.

Factor fundamental merupakan factor dasar, menampilkan kekuatan dan kelemahan dari company dan juga dapat mencerminkan company performance. Perkiraan kinerja perusahaan dapat dilakukan dengan dengan analisis fundamental yaitu dengan menganalisa companys financial performance, melalui beberapa financial ratio.

Table 1.2

Variable Data $\mathrm{X}, \mathrm{Y}, \mathrm{Z}$

\begin{tabular}{|c|c|c|c|c|c|c|c|}
\hline $\begin{array}{l}\text { Kode } \\
\text { Saham }\end{array}$ & Tahun & $\begin{array}{c}\text { DER } \\
\left(\mathrm{X}_{1}\right)\end{array}$ & $\begin{array}{l}\text { CR } \\
\left(X_{2}\right)\end{array}$ & $\begin{array}{c}\text { ROE } \\
\left(X_{3}\right)\end{array}$ & $\begin{array}{c}\mathrm{ROA} \\
\left(\mathrm{X}_{4}\right)\end{array}$ & $\begin{array}{l}\mathrm{RS} \\
(\mathrm{Y})\end{array}$ & $\begin{array}{r}\text { PBV } \\
(Z)\end{array}$ \\
\hline \multirow{7}{*}{ ASII } & 2010 & 1,10 & 1,26 & 29,13 & 12,70 & 0,57 & 4,68 \\
\hline & 2011 & 1,02 & 1,36 & 27,79 & 13,70 & 0,36 & 4,47 \\
\hline & 2012 & 1,03 & 1,40 & 25,32 & 12,50 & 0,03 & 3,68 \\
\hline & 2013 & 1,02 & 1,24 & 21,00 & 10,40 & 0,11 & 2,79 \\
\hline & 2014 & 0,96 & 1,31 & 18,40 & 9,40 & 0,09 & 2,60 \\
\hline & 2015 & 0,94 & 1,38 & 12,30 & 6,40 & 0,19 & 1,92 \\
\hline & 2016 & 0,87 & 1,24 & 13,10 & 7,00 & 0,38 & 2,54 \\
\hline \multirow{7}{*}{ AUTO } & 2010 & 0,45 & 1,76 & 29,60 & 20,40 & 1,43 & 2,93 \\
\hline & 2011 & 0,47 & 1,35 & 23,30 & 15,80 & 0,22 & 3,04 \\
\hline & 2012 & 0,62 & 1,16 & 20,70 & 12,80 & 0,09 & 2,73 \\
\hline & 2013 & 0,32 & 1,89 & 10,60 & 8,00 & 0,01 & 1,94 \\
\hline & 2014 & 0,42 & 1,33 & 9,40 & 6,70 & 0,15 & 2,08 \\
\hline & 2015 & 0,41 & 1,32 & 2,80 & 1,90 & $-0,62$ & 0,77 \\
\hline & 2016 & 0,39 & 1,51 & 4,60 & 3,30 & 0,28 & 0,96 \\
\hline \multirow{4}{*}{ BRAM } & 2010 & 0,23 & 4,02 & 12,00 & 9,00 & 0,66 & 1,05 \\
\hline & 2011 & 0,38 & 2,79 & 5,90 & 4,30 & $-0,10$ & 0,75 \\
\hline & 2012 & 0,36 & 2,13 & 13,30 & 9,80 & 0,40 & 0,86 \\
\hline & 2013 & 0,47 & 1,57 & 3,40 & 2,30 & $-0,25$ & 0,54 \\
\hline
\end{tabular}


ISSN (print) : 2598-9545 \& ISSN (online) : 2599-171X

\begin{tabular}{|c|c|c|c|c|c|c|c|}
\hline & 2014 & 0,73 & 1,42 & 8,80 & 5,20 & 1,22 & 1,04 \\
\hline & 2015 & 0,60 & 1,81 & 6,90 & 4,30 & $-0,06$ & 0,81 \\
\hline & 2016 & 0,50 & 1,89 & 11,30 & 7,50 & 0,43 & 1,19 \\
\hline \multirow{7}{*}{ GDYR } & 2010 & 1,76 & 0,86 & 16,00 & 5,80 & 0,30 & 1,30 \\
\hline & 2011 & 1,77 & 0,85 & 4,60 & 1,60 & $-0,24$ & 1,15 \\
\hline & 2012 & 1,35 & 0,89 & 12,70 & 5,40 & 0,29 & 1,02 \\
\hline & 2013 & 0,98 & 0,94 & 8,20 & 4,20 & 0,54 & 1,20 \\
\hline & 2014 & 1,17 & 0,94 & 4,70 & 2,20 & $-0,16$ & 0,97 \\
\hline & 2015 & 1,15 & 0,94 & 0,20 & 0,10 & 0,70 & 1,41 \\
\hline & 2016 & 1,01 & 0,86 & 2,90 & 1,50 & $-0,30$ & 1,07 \\
\hline \multirow{7}{*}{ GJTL } & 2010 & 1,94 & 1,76 & 23,60 & 8,00 & 4,41 & 2,40 \\
\hline & 2011 & 1,61 & 1,75 & 15,40 & 5,90 & 0,30 & 2,38 \\
\hline & 2012 & 1,35 & 1,72 & 20,70 & 8,80 & $-0,26$ & 1,60 \\
\hline & 2013 & 1,68 & 2,31 & 2,10 & 0,80 & $-0,24$ & 1,02 \\
\hline & 2014 & 1,68 & 2,02 & 4,50 & 1,70 & 0,15 & 0,84 \\
\hline & 2015 & 2,25 & 1,78 & 5,80 & 1,80 & 0,63 & 0,37 \\
\hline & 2016 & 2,20 & 1,73 & 10,70 & 3,40 & 1,02 & 0,65 \\
\hline \multirow{7}{*}{ IMAS } & 2010 & 3,97 & 1,07 & 31,60 & 6,40 & 7,84 & 9,05 \\
\hline & 2011 & 1,54 & 1,37 & 19,10 & 7,50 & 0,68 & 4,35 \\
\hline & 2012 & 2,08 & 1,23 & 15,80 & 5,10 & 0,17 & 2,68 \\
\hline & 2013 & 2,35 & 1,09 & 9,30 & 2,80 & $-0,08$ & 2,16 \\
\hline & 2014 & 2,49 & 1,03 & 1,00 & 0,30 & $-0,18$ & 1,74 \\
\hline & 2015 & 2,71 & 0,94 & 0,30 & 0,10 & 0,41 & 1,01 \\
\hline & 2016 & 2,82 & 0,92 & 4,70 & 1,20 & 0,45 & 0,59 \\
\hline \multirow{7}{*}{ INDS } & 2010 & 2,40 & 1,39 & 30,90 & 9,10 & 7,40 & 1,76 \\
\hline & 2011 & 0,80 & 2,40 & 19,00 & 10,60 & $-0,67$ & 1,41 \\
\hline & 2012 & 0,46 & 2,33 & 11,80 & 8,10 & 0,68 & 1,20 \\
\hline & 2013 & 0,25 & 3,86 & 8,40 & 6,70 & $-0,36$ & 0,87 \\
\hline & 2014 & 0,25 & 2,91 & 7,00 & 5,60 & $-0,40$ & 0,58 \\
\hline & 2015 & 0,33 & 2,23 & 0,10 & 0,10 & $-0,78$ & 0,13 \\
\hline & 2016 & 0,20 & 3,03 & 2,40 & 2,00 & 1,31 & 0,26 \\
\hline \multirow{7}{*}{ LPIN } & 2010 & 0,41 & 2,52 & 13,20 & 9,40 & 1,84 & 0,65 \\
\hline & 2011 & 0,33 & 2,89 & 9,60 & 7,20 & $-0,30$ & 0,41 \\
\hline & 2012 & 0,28 & 2,90 & 12,30 & 9,60 & 2,48 & 1,23 \\
\hline & 2013 & 0,37 & 2,48 & 6,00 & 4,40 & $-0,35$ & 0,73 \\
\hline & 2014 & 0,33 & 2,16 & 3,00 & 2,20 & 0,24 & 1,00 \\
\hline & 2015 & 1,78 & 0,79 & 15,60 & 5,60 & $-0,13$ & 1,09 \\
\hline & 2016 & 8,26 & 0,71 & 124,10 & 13,40 & 0,00 & 1,99 \\
\hline \multirow{3}{*}{ MASA } & 2010 & 0,87 & 0,67 & 10,80 & 5,80 & 0,61 & 1,29 \\
\hline & 2011 & 1,56 & 0,48 & 3,30 & 1,30 & 0,52 & 2,60 \\
\hline & 2012 & 0,68 & 1,39 & 0,10 & 0,10 & $-0,10$ & 1,27 \\
\hline
\end{tabular}




\begin{tabular}{|c|c|c|c|c|c|c|c|}
\hline & 2013 & 0,68 & 1,57 & 1,00 & 0,60 & $-0,13$ & 0,82 \\
\hline & 2014 & 0,67 & 1,75 & 0,10 & 0,10 & 0,08 & 0,84 \\
\hline & 2015 & 0,73 & 1,29 & 7,80 & 4,50 & 0,16 & 0,62 \\
\hline & 2016 & 0,80 & 1,05 & 2,00 & 1,10 & 0,23 & 0,56 \\
\hline \multirow{7}{*}{ NIPS } & 2010 & 1,28 & 1,02 & 8,50 & 3,80 & 2,98 & 0,59 \\
\hline & 2011 & 1,69 & 1,08 & 10,70 & 3,80 & 0,01 & 0,43 \\
\hline & 2012 & 1,60 & 1,11 & 10,70 & 4,10 & 0,03 & 0,45 \\
\hline & 2013 & 2,38 & 1,05 & 14,40 & 4,20 & $-0,92$ & 1,01 \\
\hline & 2014 & 1,07 & 1,29 & 8,50 & 4,10 & 0,50 & 1,43 \\
\hline & 2015 & 1,54 & 1,05 & 5,00 & 2,00 & $-0,13$ & 1,10 \\
\hline & 2016 & 1,11 & 1,22 & 7,80 & 3,70 & 0,17 & 0,80 \\
\hline \multirow{7}{*}{ PRAS } & 2010 & 2,42 & 1,45 & 0,20 & 0,10 & 0,22 & 0,73 \\
\hline & 2011 & 2,45 & 1,14 & 1,00 & 0,30 & 0,42 & 0,57 \\
\hline & 2012 & 1,06 & 1,11 & 5,60 & 2,70 & 0,93 & 0,62 \\
\hline & 2013 & 0,96 & 1,03 & 3,20 & 1,70 & $-0,27$ & 0,39 \\
\hline & 2014 & 0,91 & 1,00 & 1,70 & 0,90 & 0,10 & 0,34 \\
\hline & 2015 & 1,12 & 1,01 & 0,90 & 0,40 & 0,39 & 0,11 \\
\hline & 2016 & 1,30 & 1,01 & $-0,40$ & $-0,20$ & 0,36 & 0,22 \\
\hline \multirow{7}{*}{ SMSM } & 2010 & 0,96 & 2,17 & 29,00 & 14,10 & 0,43 & 3,04 \\
\hline & 2011 & 0,70 & 2,72 & 32,70 & 19,30 & 0,27 & 3,32 \\
\hline & 2012 & 0,76 & 1,94 & 32,70 & 18,60 & 0,86 & 4,56 \\
\hline & 2013 & 0,69 & 2,10 & 34,80 & 20,60 & 0,37 & 4,95 \\
\hline & 2014 & 0,53 & 2,11 & 36,80 & 24,20 & 0,38 & 5,97 \\
\hline & 2015 & 0,54 & 2,39 & 32,00 & 20,80 & 0,00 & 4,64 \\
\hline & 2016 & 0,43 & 2,86 & 31,80 & 22,30 & 0,18 & 3,62 \\
\hline
\end{tabular}

Sumber : Idx/ Diolah

\section{B. LANDASAN TEORI}

\section{Manajemen}

Menurut Hasibuan (2014:1) Manajemen adalah ilmu dan seni mengatur proses pemanfaatan sumber daya manusia dan sumber-sumber lainnya secara efektif dan efisien untuk mencapai suatu tujuan tertentu.

Menurut Sudarwan dan Danim (2010:18) manajemen sebagai sebuah proses yang khas, yang terdiri atas tindakan-tindakan perencanaan, pengorganisasian, menggerakan dan pengawasan, yang dilakukan untuk menentukan serta mencapai sasaran-sasaran yang telah ditetapkan melalui pemanfaatan sumber daya manusia serta sumber-sumber lain untuk mencapai tujuan tertentu.

Berdasarkan penjelasan dari beberapa pakar manajemen maka dapat disimpulkan bahwa manajemen merupakan proses perencanaan (planning), pengorganisasian (organizing), memimpin (leading) dan pengawasan (controlling) yang dilakukan untuk mencapai sasaran-sasaran yang telah ditetapkan melalui pemanfaatan sumber daya manusia serta sumber-sumber lain untuk mencapai tujuan tertentu secara efektif dan efisien. 


\section{Manajemen Keuangan}

Lawrence J. Gitman (2003:4) menyatakan bahwa keuangan dapat didefinisikan sebagai suatu seni dan ilmu pengetahuan dari pengelolaan uang. Sesungguhnya setiap individu dan organisasi menghasilkan uang dan membelanjakan atau menginvestasikan uang. Keuangan berhubungan dengan proses, institusi, pasar dan instrumen yang terlibat dalam pemindahan atau transfer uang antar individu, bisnisdan pemerintah. Riyanto (2001:4) menerangkan bahwa manajemen keuangan adalah manajemen untuk fungsi-fungsi pembelanjaan.

Berdasarkan pendapat para ahli maka dapat disimpulkan bahwa manajemen keuangan adalah segala aktifitas yang berhubungan dengan perolehan, pendanaan dan pengelolaan aktiva dengan biaya yang semurah-murahnya dan seefektif mungkin untuk menciptakan laba dan nilai tambah ekonomi (Economic Value Added) bagi suatu organisasi atau perusahaan. Agar manajemen keuangan tersebut dapat diaplikasikan dengan benar maka manajer keuangan harus bijak dalam mencari sumber dana dan cermat serta tepat dalam mengalokasikan dana tersebut karena kegiatan keuangangan merupakan urat nadi perusahaan yang harus tetap stabil dan seimbang dengan fungsi manajemen lainnya seperti manajemen pemasaran, produksi maupun sumber daya manusia.

\section{Analisis Rasio Keuangan}

Rasio keuangan sangat penting gunanya untuk melakukan analisis terhadap kondisi keuangan perusahaan yang di peroleh dari hasil operasi perusahaan. Beberapa rasio akan membantu dalam menganalisis dan menginterprestasikan posisi keuangan suatu perusahaan, dengan menggunakan laporan yang di perbandingkan, termasuk tentang perubahan-perubahan yang terjadi dalam jumlah rupiah, presentase serta trendnya.

Munawir (2010:106), Analisis rasio keuangan adalah Future oriented atau berorientasi dengan masa depan, artinya bahwa dengan analisa ratio keuangan bisa digunakan sebagai alat untuk meramalkan keadaan keuangan serta hasil usaha dimasa mendatang. Dengan angka-angka ratio historis atau kalo memungkinkan dengan angka rasio industri (yang dilengkapi dengan data lainnya) bisa digunakan sebagai dasar untuk penyusunan laporan keuangan yang diproyeksikan yang merupakan salah satu bentuk perencanaan keuangan perusahaan.

Debt to equity ratio merupakan rasio yang digunakan untuk menilai hutang dengan ekuitas. Rasio ini dicari dengan cara membandingkan antara seluruh hutang, termasuk hutang lancar dengan seluruh ekuitas.

\section{Current Ratio (CR)}

CurrentRatio (CR) merupakan salah satu jenis dari rasio likuiditas yang sering juga disebut rasio modal kerja, merupakan rasio yang digunakan untuk mengukur seberapa likuidnya suatu perusahaan. Caranya adalah dengan membandingkan komponen yang ada dineraca, yaitu total aktiva lancar dengan total passiva lancar (utang jangka pendek).

\section{Return On Equity (ROE)}

Return On Equity juga merupakan salah satu dari rasio profitabilitas. Menurut Riyanto (2001: 335) tingkat pengembalian ekuitas (Return On Equity) merupakan perbandingan antara laba bersih dengan ekuitas. 


\section{Return On Asset (ROA)}

Return On Asset (ROA) adalah rasio yang menunjukan hasil (return) atas jumlah aktiva yang digunakan dalam perusahaan. Selain itu, ROA memberikan ukuran yang lebih baik atas profitabilitas perusahaan karena menunjukan efektivitas manajemen dalam menggunakan aktiva untuk memperoleh pendapatan (Kasmir, 2012:201).

\section{Return Saham}

Return saham adalah tingkat keuntungan yang dinikmati oleh pemodal atas suatu investasi saham yang dilakukan. Return yang diterima oleh seorang pemodal yang melakukan investasi tergantung dari instruman investasi yang dibelinya/ditransaksikan. Menurut Fakhruddin (2008:169) return saham merupakan laba atas suatu investasi yang biasanya dinyatakan sebagai tarif persentase tahunan.

\section{Price to Book Value (PBV)}

Salah satu indikator fundamental dari sebuah saham adalah Price to Book Value (PBV) yang banyak digunakan oleh investor maupun analis untuk mengetahui nilai wajar saham. Indikator ini didapat dengan membagi harga saham yang ada di pasar saham dengan nilai book value dari saham tersebut. Saham yang memiliki rasio PBV yang besar bisa dikatakan memiliki valuasi yang tinggi (over value) sedangkan saham yang memiliki PBV dibawah 1 memiliki valuasi yang rendah alias under value. Price to Book Value merupakan salah satu indikator utama untuk melihat apakah suatu saham mahal atau tidak. Namun penggunaan PBV harus dilihat dari indikator lainnya juga seperti PER dan PEG ratio untuk memperkuat analisa dalam menentukan nilai wajar saham tersebut.

\section{Kerangka Berpikir}

Kerangka pemikiran merupakan suatu proses dari penelitian dalam memperoleh data kemudian mengolah data tersebut dan menginterprestasikan hasil data yang telah diolah. Berikut gambaran mengenai kerangka pemikiran sebagai berikut:

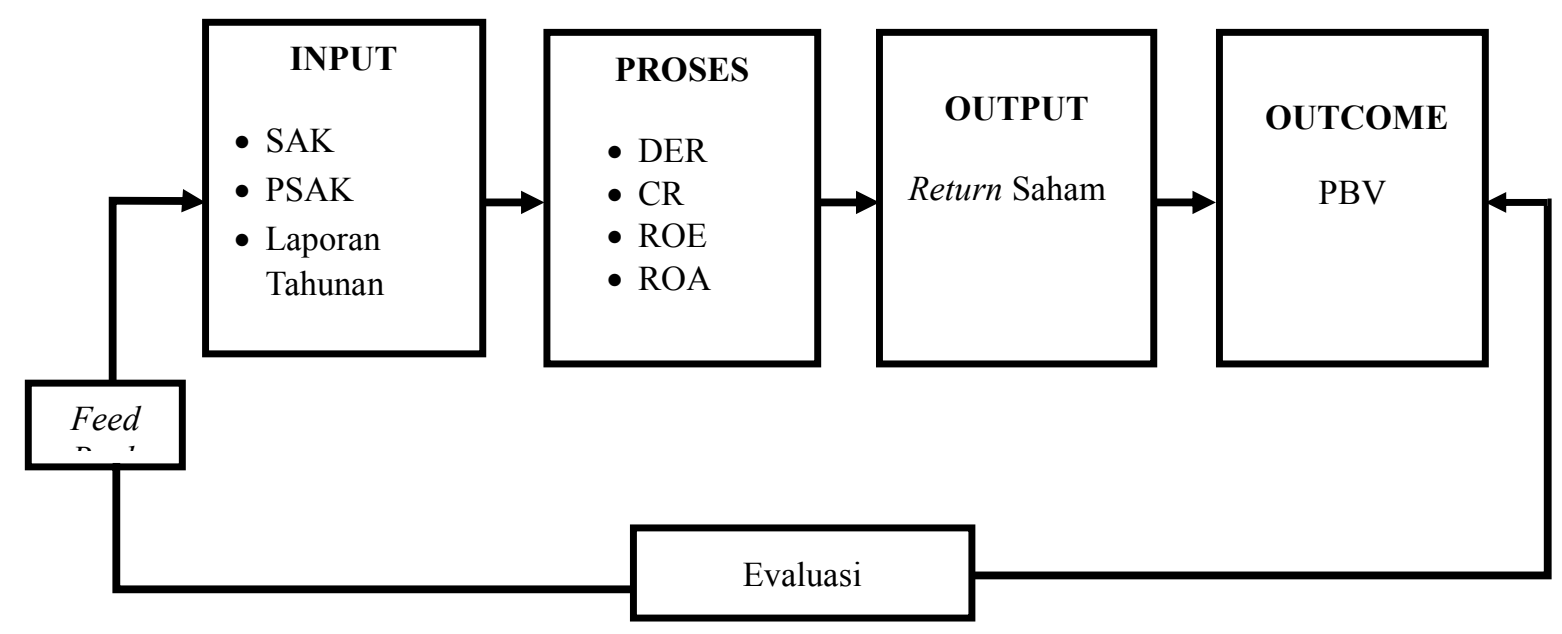

Gambar 2.1

Kerangka Pemikiran

Variabel yang diteliti adalah Debt to Equity Ratio, Current Ratio, Return On Equity, Return On Asset, Return Saham dan Price to Book Value. Objek dalam penelitian 
ini adalah 12 perusahaan otomotif yang terdaftar di Bursa Efek Indonesia. Data penelitian dianalisis menggunakan analisis regresi data panel kemudian ditarik kesimpulan dan implikasi dari hasil penelitian yang telah dilakukan.

\section{METODOLOGI PENELITIAN}

\section{Obyek Penelitian}

Penelitian dilakukan mulai bulan April 2017 sampai dengan Juni 2018 dan sampai data yang dibutuhkan dianggap cukup untuk mendukung penelitian.

2. Populasi dan Sampel

a. Populasi

Populasi dalam penelitian ini adalah 13 perusahaan industri manufaktur sektor aneka industri sub sektor otomotif yang terdaftar di Bursa Efek Indonesia (BEI)

b. Sampel Penelitian

Teknik pengambilan sampel dalam penelitian ini adalah nonprobality sampling jenis purposive sampling. Sugiyono (2012:85) sampling purposive yaitu teknik pengambilan sampel dengan pertimbangan tertentu. Pengambilan sampel dengan metode ini bertujuan untuk mendapatkan sampel yang representatif sesuai dengan kriteria sampel yang ditentukan. Adapun kriteria yang harus dipenuhi untuk menjadi sampel penelitian ini yaitu :

- Perusahaan otomotif yang terdaftar di Bursa Efek Indonesia.

- Perusahaan otomotif yang telah melakukan Initial Publik Offering (IPO) sebelum periode penelitian.

- Perusahaan otomotif yang mempublikasikan laporan tahunannya berturut-turut untuk periode penelitian yaitu terhitung sejak tahun 2010 hingga tahun 2016.

- Perusahaan otomotif yang laporan tahunannya dapat diakses dan diunduh oleh peneliti.

Berdasarkan kriteria yang telah ditetapkan tersebut maka perusahaan yang menjadi sampel dalam penelitian ini adalah sebagai berikut:

Tabel 3.1

Perusahaan Otomotif \& Komponen Yang Menjadi Sampel Penelitian

\begin{tabular}{|l|l|l|l|c|}
\hline No. & $\begin{array}{c}\text { Kode } \\
\text { Saham }\end{array}$ & \multicolumn{1}{|c|}{ Nama Emiten } & \multicolumn{1}{|c|}{ Tanggal IPO } & $\begin{array}{c}\text { Saham } \\
\text { Syariah }\end{array}$ \\
\hline 1 & ASII & Astra International Tbk & 04 April 1990 & $\sqrt{ }$ \\
\hline 2 & AUTO & Astra Otoparts Tbk & 15 Juni 1998 & $\sqrt{ }$ \\
\hline 3 & BRAM & Indo Kordsa Tbk & 05 September 1990 & $\sqrt{ }$ \\
\hline 4 & GDYR & Goodyear Indonesia Tbk & 01 Desember 1980 & $\sqrt{ }$ \\
\hline 5 & GJTL & Gajah Tunggal Tbk & 08 Mei 1990 & $\sqrt{ }$ \\
\hline 6 & IMAS & Indomobil Sukses International Tbk & 15 September 1993 & X \\
\hline 7 & INDS & Indospring Tbk & 10 Agustus 1990 & $\sqrt{ }$ \\
\hline 8 & LPIN & Multi Prima Sejahtera Tbk & 05 Februari 1990 & $\sqrt{ }$ \\
\hline 9 & MASA & Multistrada Arah Sarana Tbk & 09 Juni 2005 & $\sqrt{ }$ \\
\hline 10 & NIPS & Nipress Tbk & 24 Juli 1991 & $\sqrt{ }$ \\
\hline 11 & PRAS & Prima Alloy Steel Universal Tbk & 12 Juli 1990 & $\sqrt{ }$ \\
\hline 12 & SMSM & Selamat Sempurna Tbk & 24 September 1996 & $\sqrt{ }$ \\
\hline
\end{tabular}

\section{Metode Pengumpulan Data}

Teknik pengumpulan data yang digunakan dalam penelitian ini adalah metode dokumentasi yaitu pengumpulan data dengan mengumpulkan data sekunder dari dokumen berupa laporan keuangan yang telah dipublikasikan oleh Bursa Efek Indonesia dan juga website resmi perusahaan. 


\section{Metode Analisis Data}

Penelitian ini menggunakan metode analisis data panel karena data yang

digunakan melalui proses penyatuan antara data waktu (time series) dengan data antar individu (cross section) yang disebut dengan data panel.

Dalam penelitian ini penulis menggunakan bantuan program E-views 8.0 untuk menganalisa data yang diperoleh, yaitu mengelola Debt to Equity Ratio (DER), Current Ratio (CR), Return on Equity (ROE) dan Return on Assets (ROA) terhadap return saham serta dampaknya terhadap Price to Book Value (PVB) pada perusahaan otomotif yang terdaftar pada Bursa Efek Indonesia periode 2010 sampai dengan 2016. Setelah data dikelola lalu dilakukan interprestasi hasil yang diperoleh.

\section{HASIL DAN PEMBAHASAN}

Pengujian Kesesuaian Model

Seberapa besar variabel-variabel independen mempengaruhi variabel dependen dihitung dengan menggunakan persamaan model regresi data panel sebagaimana ditulis Agus Tri Basuki (2015:166) sebagai berikut:

$Y=a+b_{1} X_{1 i t}+b_{2} X_{2 i t}+b_{3} X_{3 i t}+b_{4} X_{4 i t}+e$

$Z=a+b_{1} Y_{i t}+e$

Dimana :

Y : Return Saham

$\mathrm{Z}$ :Price to Book Value (PBV)

a : Intercept

$\beta_{1-4}:$ Konstanta

$\mathrm{X}_{1}$ : Debt to Equity Ratio (DER)

$\mathrm{X}_{2} \quad$ : Current Ratio (CR)

$\mathrm{X}_{3} \quad$ : Return on Equity (ROE)

$\mathrm{X}_{4} \quad$ : Return on Asset (ROA)

$\mathrm{e}_{\mathrm{i}} \quad$ :Error/sesatan

Dalam metode estimasi model regresi dengan menggunakan data panel dapat dilakukan melalui tiga pendekatan, antara lain:

\section{a. Common Effect Model}

Pada model ini tidak diperhatikan dimensi waktu maupun individu, sehingga diasumsikan bahwa perilaku data perusahaan sama dalam berbagai kurun waktu. Metode ini bisa menggunakan pendekatan Ordinary Least Square (OLS) atau teknik kuadrat terkecil untuk mengestimasi model data panel.

b. Fixed Effect Model

Estimasi data panel model Fixed Effects menggunakan teknik variable dummy untuk menangkap perbedaan intersep antar perusahaan, perbedaan intersep bisa terjadi karena perbedaan budaya kerja, manajerial, dan insentif. Namun demikian slopnya sama antar perusahaan. Model estimasi ini sering juga disebut dengan teknik Least Squares Dummy Variable (LSDV).

c. Random Effect Model

Model Random Effect perbedaan intersep diakomodasi oleh error terms masingmasing perusahaan. Keuntungan menggunkan model Random Effect yakni untuk menghilangkan heteroskedastisitas. Model ini juga disebut dengan Error Component Model (ECM) atau teknik Generalized Least Square (GLS).

Selanjutnya untuk memilih metode mana yang terbaik diantara ketiga metode tersebut dilakukan uji Chow, uji Hausman dan uji lagrange multiplier. 


\section{Pengujian Hipotesis}

\section{Uji Partial (uji-T)}

Uji-t ini bertujuan untuk mengetahui besarnya pengaruh masing-masing variabel bebas secara individual (parsial) terhadap variabel terikat. Pengujian ini dapat dilakukan dengan melihat pada hasil regresi yang dilakukan dengan Program Eviews, yaitu dengan membandingkan tingkat signifikansi masing-masing variabel bebas dengan $\alpha=0,05$.

\section{Uji -F (Uji Simultan)}

Pengujian ini dilakukan untuk menguji pengaruh secara simultan variabel bebas terhadap variabel terikatnya, dimana jika variabel bebas memiliki pengaruh secara simultan terhadap variabel terikat maka model persamaan regresi masuk dalam kriteria cocok atau fit.

\section{Koefisien Determinasi (R2)}

Koefisien determinasi (R2) mengukur seberapa jauh kemampuan model dalam menerangkan variasi variabel dependen. Nilai koefisien determinasi adalah di antara nol dan satu. Nilai R2 yang kecil berarti kemampuan variabel-variabel independen dalam menjelaskan variasi variabel dependen amat terbatas. Nilai yang mendekati satu berarti variabel-variabel independen memberikan hampir semua informasi yang dibutuhkan untuk memprediksi variasi variabel dependen Ghozali (2011:87).

Dependent Variable: RETURN_SAHAM?

Method: Panel Least Squares

\begin{tabular}{lllll}
\hline \hline Variable & Coefficient & Std. Error & t-Statistic & Prob. \\
\hline \hline C & -2.134679 & 0.698485 & -3.056158 & 0.0032 \\
DER? & 1.466062 & 0.232882 & 6.295306 & 0.0000 \\
CR? & 0.100812 & 0.317877 & 0.317143 & 0.7521 \\
ROE? & 10.63671 & 1.822521 & 5.836261 & 0.0000 \\
ROA? & -6.699205 & 5.385743 & -1.243878 & 0.2178 \\
\hline \hline
\end{tabular}

Effects Specification

Cross-section fixed (dummy variables)

\begin{tabular}{llll}
\hline \hline R-squared & 0.524178 & Mean dependent var & 0.412711 \\
Adjusted R-squared & 0.419218 & S.D. dependent var & 1.377360 \\
S.E. of regression & 1.049674 & Akaike info criterion & 3.104479 \\
Sum squared resid & 74.92339 & Schwarz criterion & 3.567491 \\
Log likelihood & -114.3881 & Hannan-Quinn criter. & 3.290606 \\
F-statistic & 4.994045 & Durbin-Watson stat & 1.973019 \\
Prob(F-statistic) & 0.000002 & & \\
\hline
\end{tabular}

Sumber : data diolah

Dependent Variable: PBV?

Method: Panel Least Squares

\begin{tabular}{lllll}
\hline \hline Variable & Coefficient & Std. Error & t-Statistic & Prob. \\
\hline \hline
\end{tabular}




\begin{tabular}{lrrrr} 
C & 1.512325 & 0.097124 & 15.57106 & 0.0000 \\
RETURN_SAHAM? 0.445849 & 0.069651 & 6.401203 & 0.0000 \\
\hline
\end{tabular}

Effects Specification

Cross-section fixed (dummy variables)

\begin{tabular}{llll}
\hline \hline R-squared & 0.734797 & Mean dependent var & 1.696332 \\
Adjusted R-squared & 0.689974 & S.D. dependent var & 1.527077 \\
S.E. of regression & 0.850276 & Akaike info criterion & 2.654876 \\
Sum squared resid & 51.33083 & Schwarz criterion & 3.031074 \\
Log likelihood & -98.50478 & Hannan-Quinn criter. & 2.806104 \\
F-statistic & 16.39329 & Durbin-Watson stat & 0.852960 \\
Prob(F-statistic) & 0.000000 & & \\
\hline
\end{tabular}

Sumber : data diolah

\section{Pengujian Kesesuaian Model}

\section{Uji Chow (Chow Test)}

Pada variabel X1, X2, X3, X4 terhadap $Y$

Nilai probabilitas (prob) cross section $\mathrm{F}$ adalah $0,0025<0,005$ hal ini berarti $\mathrm{H} 0$ ditolak dan $\mathrm{H} 1$ diterima sehingga model Fixed Effect lebih tepat dibandingkan dengan Common Effect Model.

Pada variabel $Y$ terhadap $Z$

Nilai probabilitas (prob) cross section $\mathrm{F}$ adalah $0,0000<0,005$

hal ini berarti $\mathrm{HO}$ ditolak dan $\mathrm{H} 1$ diterima sehingga Fixed Effect Model lebih tepat dibandingkan dengan Common Effect Model.

\section{Uji Hausman (Hausman Test)}

Pada variabel $\mathrm{X} 1, \mathrm{X} 2, \mathrm{X} 3, \mathrm{X} 4$ terhadap $\mathrm{Y}$

Nilai probabilitas cross section random adalah $0,0000<0,05$ dapat disimpulkan bahwa $\mathrm{H} 0$ ditolak dan $\mathrm{H} 1$ diterima dan metode yang paling tepat adalah fixed effect model.

Pada variabel $Y$ terhadap $Z$

Nilai probabilitas cross section random adalah 0,8446 > 0,05 maka HO diterima sehingga model yang digunakan adalah random effect model.

\section{Uji Langrange Multiplier (LM Test)}

Dalam penelitian ini uji Langrange Multiplier hanya dilakukan pada veriabel $Y$ terhadap $Z$ dan tidak dilakukan pada variabel X1, X2, X3, X4 terhadap Y karena berdasar uji Chow dan uji Hausman diketahui model yang paling tepat digunakan adalah model fixed effect.

Dasar pengambilan keputusan dalam uji ini dapat dilakukan dengan melihat nilai cross section random. Apabila nilainya $<0,05$ maka $\mathrm{H} 0$ diterima dan model yang tepat adalah Common Effect Model, namun jika nilainya < 0,05 maka H0 ditolak dan $\mathrm{H} 1$ diterima dan model yang paling tepat adalah Random Effect Model. Hasil uji menunjukkan nilai probabilitas Breusch-Pagan adalah 0,0000. Ini berarti bahwa nilai cross section random< 0,05 sehingga $\mathrm{H} 0$ ditolak dan $\mathrm{H} 1$ diterima artinya model yang cocok digunakan adalahrandom effect model. 


\section{Uji Partial (uji-T)}

Pengaruh DER terhadap Return Saham

Hasil t-hitung variabel DER (X1) sebesar 1,496104. Sementara t-tabel dengan a $=5 \%$ dan $\mathrm{df}=(\mathrm{n}-\mathrm{k})=12-4=8$, maka $\mathrm{t}$-tabel $(0,05 ; 8)=2,30600$ (uji dua arah). Sehingga t-hitung $<$ t-tabel $(1,496104<2,30600)$ maka H0 diterima dan $\mathrm{H} 1$ ditolak. Dengan signifikansi (prob) 0,1391 >0,05 sehingga dapat dikatakan bahwa secara parsial variabel DER (X1) tidak berpengaruh signifikaan terhadap Return Saham (Y).

\section{Pengaruh CR terhadap Return Saham}

Hasil t-hitung variabel CR $(X 2)$ sebesar $-1,255304$. Sementara t-tabel dengan a $=5 \%$ dan $\mathrm{df}=(\mathrm{n}-\mathrm{k})=12-4=8$, maka t-tabel $(0,05 ; 8)=2,30600$ (uji dua arah). Sehingga thitung < t-tabel $(-1.255304<2,30600)$ maka HO diterima dan H1 ditolak. Dengan signifikansi (prob) 0,2135 > 0,05 dapat dikatakan bahwa secara parsial variabel CR (X2) tidak berpengaruh signifikaan terhadap Return Saham.

\section{Pengaruh ROE terhadap Return Saham.}

Hasil t-hitung variabel ROE (X3) sebesar 2,977309. T-tabel dengan $a=5 \%$ dan df $=$ $(n-k)=12-4=8$, maka t-tabel $(0,05 ; 8)=2,30600$ (uji dua arah). Sehingga t-hitung $>t-$ tabel $(2,977309>2,30600)$ maka HO ditolak dan H1 diterima. Dengan signifikansi (prob) $0,0040<0,05$ artinya secara parsial ROE (X3) berpengaruh signifikaan terhadap Return Saham.

\section{Pengaruh ROA terhadap Return Saham}

Hasil t-hitung variabel ROA (X4) sebesar 2,885966. T-tabel dengan a $=5 \%$ dan $\mathrm{df}=$ $(n-k)=12-4=8$, maka t-tabel $(0,05 ; 8)=2,30600$ (uji dua arah). Sehingga t-hitung $>$ ttabel $(2,885966>2,30600)$ maka $\mathrm{H} 0$ ditolak dan $\mathrm{H} 1$ diterima. Dengan signifikansi (prob) 0,0052 < 0,05 artinya secara parsial ROA (X4) berpengaruh signifikaan terhadap Return Saham.

\section{Uji Partial (uji-T) Variabel Y terhadap Z}

Hasil t-hitung variabel Return Saham $(Y)$ sebesar 6,401029. T-tabel dengan a $=5 \%$ dan

$\mathrm{df}=(\mathrm{n}-\mathrm{k})=12-1=11$, maka t-tabel $(0,05 ; 8)=2,20099$ (uji dua arah). Sehingga $\mathrm{t}-$ hitung > t-tabel $(6,401029>2,20099)$ maka HO ditolak dan H1 diterima. Dengan signifikansi (prob) 0,0000 < 0,05 artinya secara parsial Return Saham (Y) berpengaruh signifikaan terhadap Price to Book Value (PBV).

\section{Uji-F (Uji Simultan)}

Hasil uji $F$ variabel $X 1, X 2, X 3$ dan $X 4$ terhadap $Y$.

Nilai probabilitas $(F$-statistic) sebesar $0.000002<$ tingkat signifikansi 0,05 sehingga $\mathrm{H} 0$ ditolak dan $\mathrm{H} 1$ diterima, artinya variabel $\mathrm{X} 1, \mathrm{X} 2, \mathrm{X} 3$ dan $\mathrm{X} 4$ signifikan terhadap $\mathrm{Y}$ secara simultan. Kemudian nilai F-hitung (F-statistic) sebesar 4.994045. Nilai Ftabel dengan $\alpha=5 \%(0,05)$ dan df $(k-1)=(4-1)=3$ dan df2 $(n-k)=84-4=80$ menunjukkan angka 2,72. Dengan demikian nilai F-hitung (4.994045) > nilai F-tabel $(2,72)$, jadi $\mathrm{HO}$ ditolak dan $\mathrm{H} 1$ diterima artinya terdapat pengaruh antara variabel bebas terhadap variabel terikat secara simultan. Persamaan Model Regresi Pada Variabel X1, X2, X3 dan X4 terhadap Y adalah sebagai berikut:

\section{$Y=-2.134679+1.466062 X 1+0.100812 X 2+10.63671 X 3-6.699205 X 4$}

Bentuk persamaan regresi tersebut dapat diartikan sebagai berikut : 
a. a (konstanta) sebesar -2.134679 berarti bahwa apabila tidak ada variabel $\mathrm{X} 1$, $\mathrm{X} 2$, X3 dan X4 maka besarnya nilai $\mathrm{Y}$ (return saham) adalah sebesar -2.135 dengan asumsi faktor- faktor lain adalah konstan.

b. $b 1=1.466062$. Koefisien regresi $X 1$ sebesar 1.466062 menunjukkan bahwa $X 1$ mempunyai arah koefiesien regresi positif yang berarti setiap kenaikan $X 1$ sebesar $1 \%$ akan menaikkan $Y$ sebesar 1.466062 satuan dan begitu juga sebaliknya, dengan asumsi faktor- faktor lain adalah konstan.

c. b2 $=0.100812$. Koefisien regresi $X 2$ sebesar 0.100812 menunjukkan bahwa $X 2$ mempunyai arah koefiesien regresi positif yang berarti setiap kenaikan X2 sebesar $1 \%$ akan menaikan $Y$ sebesar 0.100812 satuan dan begitu juga sebaliknya, dengan asumsi faktor- faktor lain adalah konstan.

d. b3=10.63671. Koefisien regresi X3 sebesar 10.63671 menunjukkan bahwa X3 mempunyai arah koefiesien regresi positif yang berarti setiap kenaikan X3 sebesar $1 \%$ akan menaikkan $Y$ sebesar 10.63671 satuan dan begitu juga sebaliknya, dengan asumsi faktor- faktor lain adalah konstan.

e. b4 $=-6.699205$. Koefisien regresi X4 sebesar -6.699205 menunjukkan bahwa X4 mempunyai arah koefiesien regresi negatif yang berarti setiap kenaikan X4 sebesar 1\% akan menurunkan $Y$ sebesar 6.699205 satuan, begitu juga sebaliknya dengan asumsi faktor lain adalah konstan.

\section{Koefisien Determinasi}

Berdasarkan hasil analisis, besarnya angka R Squared (R2) DER, CR, ROE, ROA terhadap Return Saham adalah 0.524178. Hal ini menunjukkan bahwa prosentase pengaruh variabel bebas terhadap variabel terikat adalah sebesar $52,42 \%$. artinya kemampuan variable-variabel independen dalam menjelaskan variasi dependen sebesar 52,42 persen, sisanya 47,58 persen dijelaskan oleh variabel-variabel lain di luar variabel yang diteliti. Sedangkan besarnya angka $R$ Squared variabel Return Saham (Y) terhadap PricetoBookValue (Z) adalah 0.335814. Hal ini menunjukkan bahwa prosentase pengaruh variabel bebas terhadap variabel terikat adalah sebesar $33,58 \%$. Sedangkan sisanya $66,42 \%$ dipengaruhi faktor lain di luar model regresi tersebut.

\section{E. KESIMPULAN}

Setelah melakukan pengelolahan data dengan bantuan software Eviwes 9 maka dapat diketahui hasil riset maka dapat disimpulkan:

1. Rasio variabel (X1) secara parsial tidak adanya pengaruh dan signifikan terhadap variabel $(\mathrm{Y})$. dari riset inii memperkuat penelitian Rendi Prakoso (2016).

2. Rasio variabel (X2) secara parsial tidak adanya pengaruh dan signifikan terhadap variabel $(Y)$. dari riset inii memperkuat penelitian yang dilakukan Subalno (2009) dan Rendi Prakoso (2016).

3. Rasio variabel (X3) secara parsial pengaruh positif dan signifikan terhadap variabel $(\mathrm{Y})$. dari riset inii memperkuat penelitian yang dilakukan Aryanti Mawardi (2016).

4. Rasio variabel (X4) secara parsial pengaruh positif dan signifikan terhadap variabel (Y). dari riset inii memperkuat penelitian Rendi Prakoso (2016).

5. Rasio variabel $X$ secara bersamaan pengaruh dan signifikan terhadap variabel (Y).

6. Rasio variabel $(\mathrm{Y})$ secara parsial pengaruh positif dan signifikan terhadap variabel (Z). dari riset inii memperkuat hasil penelitian Zaenal Abidin (2017). 


\section{Saran}

a. Rasio DER riset tidak memiliki pengaruh dan signifikan terhadap Return Saham. industrial company manufaktur sektor aneka industri sub sektor otomotif yang tercantum di BEI, rasio ini dapat digunakan investor membuat keputusan investasi.

b. Rasio CR riset tidak memiliki pengaruh dan signifikan terhadap Return Saham. industrial company manufaktur sektor aneka industri sub sektor otomotif yang tercantum di BEI, rasio ini dapat digunakan investor membuat keputusan investasi.

c. Rasio ROE riset memiliki pengaruh positif dan signifikan terhadap Return Saham. industrial company manufaktur sektor aneka industri sub sektor otomotif yang tercantum di $\mathrm{BEI}$, rasio ini dapat digunakan investor membuat keputusan investasi.

d. Rasio ROA riset memiliki pengaruh positif dan signifikan terhadap Return Saham. industrial company manufaktur sektor aneka industri sub sektor otomotif yang tercantum di BEI, rasio ini dapat digunakan investor membuat keputusan investasi.

e. Rasio Return Saham riset memiliki pengaruh positif dan signifikan terhadap rasio PBV. industrial company manufaktur sektor aneka industri sub sektor otomotif yang tercantum di $\mathrm{BEI}$, sehingga rasio ini dapat digunakan investor membuat keputusan investasi.

\section{DAFTAR PUSTAKA}

Basuki, Agus. T dan Imamudin. Y, 2015, Elektronik Data prosesing (SPSS dan Eviews 7), Yogyakarta: Danisa Media

Mawardi, Aryanti. 2016. "Pengaruh ROA, ROE, NPM dan CR Terhadap Return Saham pada Perusahaan yang Terdaftar di Jakarta Islamic Index (JlI)". Jurnal I-Finance Vol. 2 No.2 Desember 2016.

Munawir. S, 2010, Analisis Laporan Keuangan Edisi Keempat, Cetakan ke lima belas", Yogyakarta: Liberty

Hakim, L., Sunardi, N. (2017). Determinant of leverage and it's implication on company value of real estate and property sector listing in IDX period of 2011-2015. Man in India, 97(24), pp. 131-148

Prakoso, Rendi. 2016. "Analisis Faktor- Faktor Yang Mempengaruhi Return Saham". Publikasi Ilmiah. Universitas Muhammadiyah Surakarta. 2016.

Subalno. 2009. "Analisis Pengaruh Faktor Fundamental dan Kondisi Ekonomi Terhadap Return Saham (Studi Kasus Pada Perusahaan Otomotif dan Komponen Yang Listed di BEI Periode 2003-2007)". Thesis. Universitas Diponegoro.

Sugiyono, 2012, Metode Penelitian Kuantitatif, dan Kualitatif ". Alfabeta, Bandung.

Suprapto, Tommy, 2009, Pengantar Teori \& Manajemen Komunikasi, Jakarta: Medpress

Kadim, A., Sunardi, N., \& Husain, T. (2020). The modeling firm's value based on financial ratios, intellectual capital and dividend policy. Accounting, 6(5), 859-870.

Terry. G dan Leslie. W. R, 2015, "Dasar-Dasar Manajemen", Cetakan Ketigabelas, PT Bumi Aksara, Jakarta.

Triagustina, dkk. 2015, "Pengaruh Return on Asset (ROA) dan Return on Equity (ROE) Terhadap Nilai Perusahaan Pada Perusahaan Manufaktur Subsektor Makanan dan Minuman Yang Terdaftar di Bursa Efek Indonesia Periode 2010-2012", Prosiding Akuntansi, Vol. 1, No. 2, 29-34.

Usman, Husaini, 2013, "Manajemen, Teori, Praktik, dan Riset Pendidikan" - Ed,4 Cet, 1-, Bumi Aksara, Jakarta. 